\title{
Erratum to: Coordination of grasping and walking in Parkinson's disease
}

Frederic Albert • Gudrun Diermayr •

Tara L. McIsaac • Andrew M. Gordon

Published online: 26 March 2010

(C) Springer-Verlag 2010

\section{Erratum to: Exp Brain Res}

DOI 10.1007/s00221-010-2179-5

Unfortunately, one of the author's names is misspelled and is incorrectly appearing in the published version of the article as Gudrun Diemayr instead of Gudrun Diermayr. This is now corrected here.

The online version of the original article can be found under doi:10.1007/s00221-010-2179-5.

F. Albert · G. Diermayr · T. L. McIsaac - A. M. Gordon ( $\square)$ Department of Biobehavioral Sciences, Teachers College, Columbia University, 525 West 120th Street, Box 199, New York, NY 10017, USA

e-mail: ag275@columbia.edu

\section{F. Albert}

Laboratoire de Neurobiologie Humaine, UMR 6149,

Université de Provence/CNRS, Pôle 3C, Case B,

3 Place Victor Hugo, 13331 Marseille Cedex 03, France

\section{A. M. Gordon}

Department of Rehabilitation Medicine,

College of Physicians and Surgeons,

Columbia University, New York, NY 10032, USA 